\title{
Micro Finance Role in Empowering Women of Telangana Region's Rural SHG
}

\author{
${ }^{* 1}$ Sreenivas Velivala, ${ }^{2}$ A Francis Abraham, ${ }^{3}$ A Kotishwar \\ ${ }^{* 1}$ Research Scholar, Annamalai University and Accounts Officer, CMR College of Engineering and Technology, \\ Hyderabad, Telangana, India \\ sreenivasvelivala@cmrcet.ac.in \\ ${ }^{2}$ Assistant Professor, Annamalai University, Tamil Nadu, India \\ francissct@rediffmail.com \\ ${ }^{3}$ Professor \& Head, Department of Master of Business Administration, CMR College of Engineering and \\ Technology, Hyderabad, Telangana, India \\ hodmba@cmrcet.org
}

Received: $11^{\text {th }}$ November 2021, Accepted: $6^{\text {th }}$ December 2021, Published: $31^{\text {st }}$ December 2021

\begin{abstract}
Empowerment is the power given to or acquire by an individual or group for the self determination and autonomy. It enhances the level of confidence and determination to prove the mettle and bring out the hidden performance and talent in someone. Micro finance is also not different from this which would make the self help group self sufficient and confident enough in doing some business related activity, which improves way of livelihood of people and an entrepreneur as a whole. Recent history is very well evident regarding role of micro finance in uplifting weaker sections of society to great extent, and has improved the life style and standard.

Purpose - The reason of the study is to find out the job of micro finance in empowering Indian women category, especially while the entire world is facing severe financial crisis and funds allocation plays a significant role.

Data / Design/ Methodology/ Approach - the data collected and treated properly by using statistical tools and SPSS

Findings - in the findings it was found that most of the women believed that micro finance facility brought a significant change in their lives as they could give the push to their small businesses.

Originality / Value - the research was conducted keeping the research ethics in mind, and seen that data collected is genuine and authentic
\end{abstract}

\section{Keywords: Micro finance, Women Empowerment, $N G O, S H G$}

\section{Introduction}

Microfinance in one sense helps the self help group to come out with their potentiality by making the self sufficient in the financial aspect of doing something innovative and serving self and others. The concept of micro finance is boost for those who wanted to stand and do some service to the society and for themselves and contribute something to the economy of the country as a whole. Micro finance has played a significant role in the still developing countries and removing the pre conceived notion that men are born to do business and service to the society, and it's not right women also has that potential and they are not different from men in doing something new and withstanding the pressures of competition and business acumen. Today young generation and women are the most expected category to do something innovative and constructive, as that passion and zeal is found in them to contribute something to the countries' economic condition improving. Microfinance concept came to existence only keeping the women category in mind as in them there is 
abundant potentiality is found by various studies and research. Micro finance has not only played critical role in providing financial support to the self help groups but also in eliminating the ancient notion of gender discrimination, and to great level it's been proved that women has that capacity and gut feeling. There are so many examples have been set by women for the generations to come by proving their mettle in the world of business and innovation. Micro finance has came as the boon for the women in the recent times that successfully brought a revolution in the women and weaker sections of the society by making them self reliant and sufficient. Particularly speaking the Telangana region is also having the same history as the rest of the world concerning women and low finance business, which works with lots of under facilities. This study particularly tries to focus those regions of Telangana which are not bestowed with abundant resources and leniencies for the women category. Recent survey and studies have proved that the societies that discriminates women and weaker sections of the societies have paid the consequences for the longer period of time in coping up the outcomes of the mistakes done by them. Micro finance genuinely gives them the opportunities to overcome the errors that have been done by them by just sanctioning to the women category of people.

\section{Review of Literature}

View of strengthening: What is strengthening? When will the state of an individual improved? Amartaya Sen(1993)illuminates that the autonomy to lead various sorts of life is reflected face to face's capacity set. The capacity of an individual relies upon an assortment of variables, including individual constructions and social exercises.

Malhotra(2002)foundations created by different creators in various fields of sociologies. Taking into consideration comparability, the different foundations recommend those ladies strengthening needs to happen along many folds and regions including: political, lawful financial matters socio-social, familial/relational, lawful, political and furthermore mental.

The World Bank characterizes strengthening as "the most common way of mounting the limit of people or gatherings to simply decide to change those decisions into wanted activities and results.

As per Krishna (2003) strengthening implies developing capacity of people or gatherings to make genuine extension and life receptions and to change over these appropriations into wanted activities and results. It is essentially an interaction and additionally results.

Microfinance and Women Empowerment: A larger piece of microfinance programs target women with the goal unequivocal of drawing in them. There are fluctuating secret motivations for seeking after women fortifying. Fight of few women is among the most unlucky and the frailest of the mistreated and helping them with being truly significant. However, other acknowledges that placing assets into women's capacity draws in them to improve things. It is a lot of recorded that an augmentation in ladies resources achieves the flourishing of the family, especially young people (Mayoux, 1997; Kabeer, 2001; Hulme and Mosley, 1997).A more ladies extremist viewpoint nerves that an extended permission to financial organizations address an opening/opportunity for more noticeable fortifying. Such affiliation unequivocally considers smaller than normal cash to be a device in the fight for the women's honors and independence. Ranjula Bali Swain (2007) Can Microfinance Empower Women? Self improvement Gatherings in India finished various walks and have made in the correct manner and ladies are throughout engage themselves and furthermore their wards.

\section{Statement of the Problem}

From time immemorial women has been considered as the house toy and restricted to only kitchen. This notion of men and rotten society had buried the hidden talent in them. Now the right time has come to given women their space and resources which could make self sufficient and independent, not only this but the passion in them would definitely allow them to create employment opportunists for other like minded with full potentiality in them. 


\section{Research Objectives}

1. To identify the stage for execution of the improvement meeting

2. To distinguish the obstructions ladies face because of male predominance

3. To comprehend the free space ladies gets in self improvement gathering

4. To assess the strengthening of the ladies mentally, monetarily and sociologically.

5. To bid ideas for the advancement of ladies' strengthening in Self Help Group.

\section{Methodology}

Design of Data: The review is initiated in provincial spaces of Telangana district. The essential auxiliary is utilized. Essential information is listed from a field review in the review area. The study is confined to the rural areas of Telangana state. The information was made uniquely from those occupied with pay making occasions. Auxiliary information is gathered from non government organization reports and the assets. One non government organization is chosen and six Self Help Groups advanced by the non government organization in country spaces of Telangana are taken for study. Regions considered under the review are:

1. Mehboobnagar

2. Nizamabad

3. Warangal

4. Kareemnagar

5. Rangareddy

6. Hyderabad

Technique for examining: In this review the strategies for testing followed are Cluster inspecting and region testing. As the taking part respondents are enormous in number they are partitioned by gatherings and haphazardly chose for information assortment.

Size of sample: All the six rural areas have been selected to collect the sample of the Telanagan state.

Statistical techniques considered: Basic relationship coefficient, matched t test, cross classification and rate examination has been utilized.

Information assortment method: An organized meeting plan was ready by the analyst and utilized to gather information from the Self Help Group's ladies individuals occupied by means of Micro ventures miniature money.

\section{Results}

36 percent of the respondents were uneducated and most of the women have done up to secondary education only. 92 percent of the ladies expressed miniature money had decreased their want level. Out of 181 respondents 130 said that they were ready to keep up with their family, followed by 44 respondents who accredited to more remarkable degree, they were ready to keep up with their family in the effort of participating in Self Help Group. Out of 181 respondents 164 moving independently without their family, followed by 17 respondents who accredited to move with their family. The majority of the respondents ( 97.2 percent) accepted that they play a fundamental role in decision making in their house. 91 respondents got miniature money to begin new pay creating business. The relationship between Improvement in proficiency level and mindfulness in kids schooling is .503 which is a high critical positive connection showing that Improvement in respondent's proficiency level prompts mindfulness in youngster's instruction. The relationship between decrease in destitution level and perfection in way of life of respondents are categorically associated. However, decrease in destitution level doesn't prompt better quality of living. 


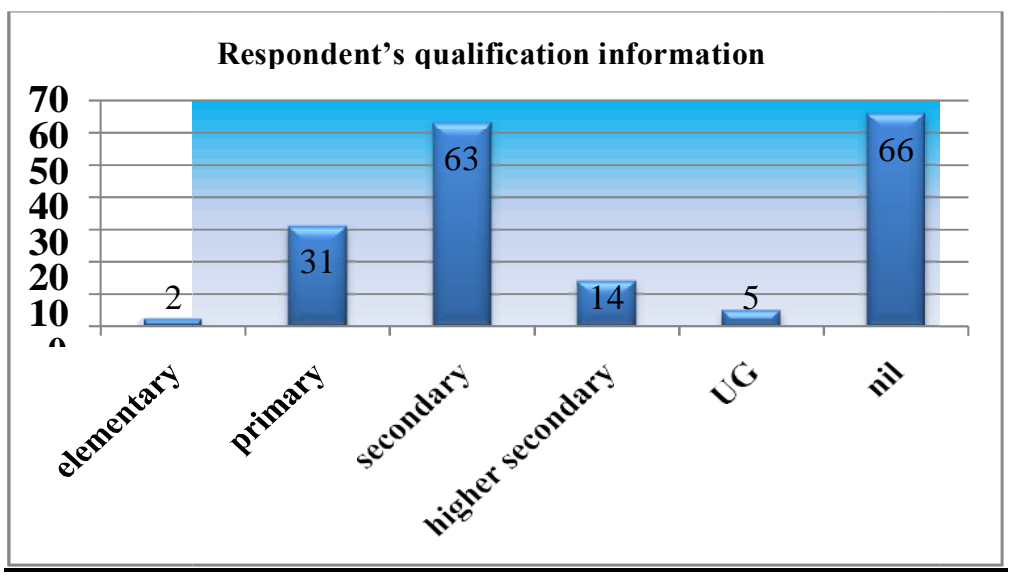

Fig 1: Qualification Status of Participants

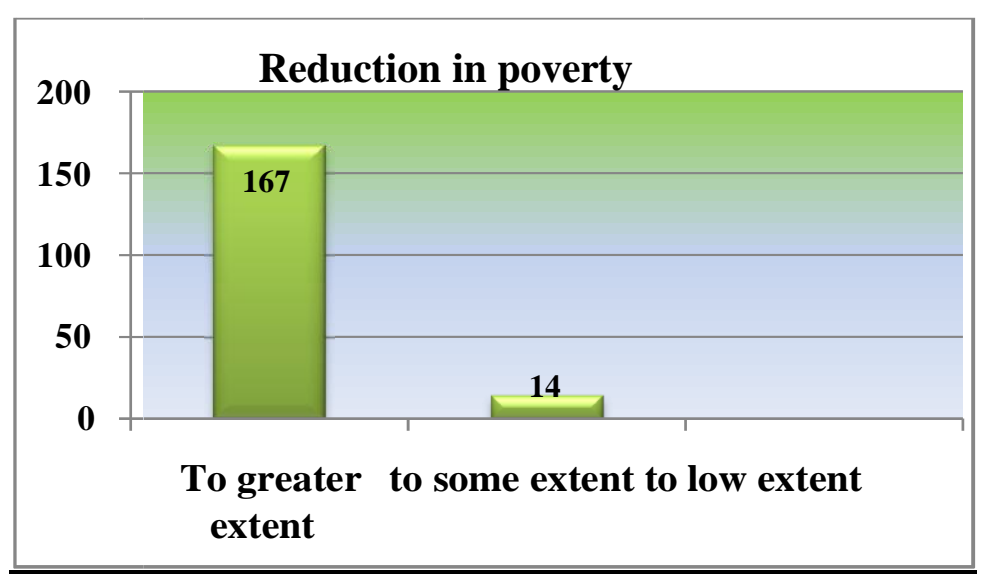

Fig 2: Satisfaction Status at economic level of Participants

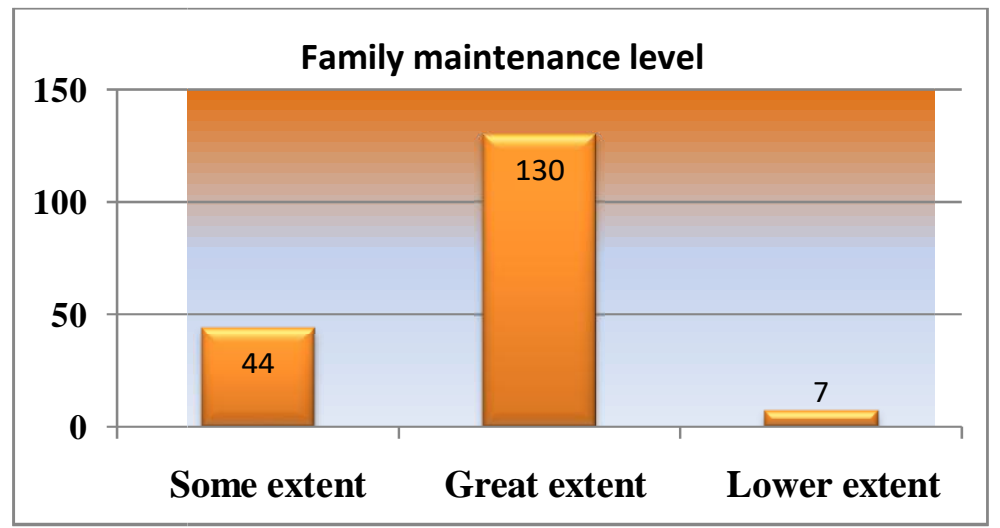

Fig 3: Satisfaction Status at Family overall maintenance level of Participants 
Helix (2021) 11 (6): 24-31

Table 1: Respondents empowered socially

\begin{tabular}{|c|c|c|c|}
\hline \multicolumn{2}{|c|}{ Independent movement } \\
\hline Sl.No & Options & Frequency & Percentage \\
\hline 1 & Yes & 164 & 90.6 \\
\hline 2 & No & 017 & 09.4 \\
\hline \multicolumn{2}{|c|}{ Total } & 181 & 100.0 \\
\hline
\end{tabular}

Table 2: Respondents empowered at family level

\begin{tabular}{|c|c|c|c|}
\hline \multicolumn{2}{|c|}{ decision making level in family } \\
\hline Sl.No & Options & Frequency & Percentage \\
\hline 1 & Yes & 176 & 97.2 \\
\hline 2 & No & 005 & 02.8 \\
\hline \multicolumn{2}{|c|}{ Total } & 181 & 100.0 \\
\hline
\end{tabular}

Table 3: Causes of availing micro finance

\begin{tabular}{|c|l|c|c|}
\hline \multicolumn{2}{|c|}{ Reason for availing micro finance } \\
\hline Sl.No & \multicolumn{1}{|c|}{ Options } & Frequency & Percentage \\
\hline 1 & Domestic utility & 34 & 18.8 \\
\hline 2 & Business venture & 91 & 50.3 \\
\hline 3 & Support business & 35 & 19.3 \\
\hline 4 & Education tutoring & 8 & 4.4 \\
\hline 5 & Lesser interest rate & 13 & 7.2 \\
\hline Total & & 181 & 100.0 \\
\hline
\end{tabular}

Table 4: Connection between progress in proficiency level and mindfulness in youngster schooling

\begin{tabular}{|l|c|c|c|}
\hline \multicolumn{2}{|c|}{ Variables } & $\begin{array}{c}\text { Improvement } \\
\text { in education } \\
\text { level }\end{array}$ & $\begin{array}{c}\text { Awareness of } \\
\text { education }\end{array}$ \\
\hline \multirow{3}{*}{ Progress in literacy level } & Rank Correlation & 1 & $\mathbf{5 0 3}^{* * *}$ \\
\cline { 2 - 3 } & $\mathrm{Sig}(2$-tailed) & & .000 \\
\cline { 2 - 3 } & $\mathrm{N}$ & 181 & 181 \\
\hline \multirow{3}{*}{ Alertness in child education } & $\begin{array}{c}\text { Pearson } \\
\text { Correlation }\end{array}$ & $\mathbf{. 5 3}^{* * *}$ & 1 \\
\cline { 2 - 4 } & Sig(2-tailed) & .000 & 181 \\
\cline { 2 - 3 } & $\mathrm{N}$ & 181 & \\
\hline
\end{tabular}


Table 5: Relationship between lessen in neediness level and improvement in way of life

\begin{tabular}{|l|c|c|c|}
\hline \multicolumn{2}{|c|}{ Variables } & $\begin{array}{c}\text { Reduce in } \\
\text { Poverty } \\
\text { level }\end{array}$ & $\begin{array}{c}\text { Improvement in } \\
\text { Standard of living }\end{array}$ \\
\hline \multirow{2}{*}{$\begin{array}{c}\text { Diminishing poverty } \\
\text { level }\end{array}$} & Rank Correlation & 1 & $\mathbf{3 7 3}$ \\
\cline { 2 - 4 } & Sig(2-tailed) & & .000 \\
\cline { 2 - 4 } & $\mathrm{N}$ & 181 & 181 \\
\hline \multirow{2}{*}{$\begin{array}{c}\text { Progress in standard of } \\
\text { living }\end{array}$} & $\begin{array}{c}\text { Pearson } \\
\text { Correlation }\end{array}$ & $\mathbf{. 3 7 3}$ & 1 \\
\cline { 2 - 4 } & Sig(2-tailed $)$ & .000 & 181 \\
\cline { 2 - 4 } & $\mathrm{N}$ & 181 & \\
\hline
\end{tabular}

Hypothesis

H0: There is no difference in mean income before and after joining Self help group.

Table 6: Paired t Test results

\begin{tabular}{|c|c|c|c|c|}
\hline Income & Mean & $\mathrm{N}$ & Std. Deviation & Std Error Mean \\
\hline $\begin{array}{c}\text { Income of respondents before } \\
\text { joining SHG's }\end{array}$ & 1016.20 & 181 & 730.507 & 54.601 \\
\hline $\begin{array}{c}\text { Income of respondents after joining } \\
\text { SHG's }\end{array}$ & 1512.85 & 181 & 889.626 & 66.494 \\
\hline
\end{tabular}

Table 7: Consolidated Statistical Inference

\begin{tabular}{|c|c|c|c|c|c|}
\hline Mean & SD & $\begin{array}{c}\text { Std Error } \\
\text { Mean }\end{array}$ & $\mathrm{t}$ & $\mathrm{df}$ & $\begin{array}{c}\text { Sig } \\
\text { value }\end{array}$ \\
\hline-497.00 & 691.00 & 52.00 & -9.00 & 180 & $\mathbf{. 0 0 0}$ \\
\hline
\end{tabular}

Table 8: Correlation data results among various age groups

\begin{tabular}{|c|c|c|c|c|c|c|c|c|c|}
\hline & \multicolumn{9}{|c|}{ Respondents Age } \\
\hline & \multicolumn{2}{|c|}{$\begin{array}{c}20- \\
30\end{array}$} & \multicolumn{2}{|c|}{$\begin{array}{c}31- \\
40\end{array}$} & \multicolumn{2}{|c|}{$41-50$} & \multicolumn{2}{|c|}{$\begin{array}{l}51- \\
60\end{array}$} & \multirow[t]{2}{*}{ TOTAL } \\
\hline & Yes & No & Yes & No & Yes & No & Yes & No & \\
\hline confidence & 85 & 0 & 40 & 0 & 31 & 0 & 25 & 0 & 181 \\
\hline Courage & 90 & 0 & 35 & 0 & 36 & 0 & 20 & 0 & 181 \\
\hline skills & 93 & 0 & 30 & 0 & 38 & 1 & 20 & 2 & 181 \\
\hline literacy & 76 & 9 & 22 & 11 & 18 & 13 & 7 & 25 & 181 \\
\hline $\begin{array}{c}\text { children } \\
\text { education } \\
\text { awareness }\end{array}$ & 78 & 7 & 40 & 7 & 18 & 10 & 10 & 11 & 181 \\
\hline
\end{tabular}


Helix (2021) 11 (6): 24-31

\begin{tabular}{|l|c|c|c|c|c|c|c|c|c|}
\hline $\begin{array}{c}\text { Awareness } \\
\text { of } \\
\text { situation }\end{array}$ & 84 & 1 & 38 & 2 & 31 & 0 & 21 & 4 & $\mathbf{1 8 1}$ \\
\hline $\begin{array}{c}\text { contentment } \\
\text { and peace }\end{array}$ & 83 & 3 & 38 & 1 & 29 & 2 & 23 & 2 & $\mathbf{1 8 1}$ \\
\hline
\end{tabular}

\section{Findings}

$>$ It is seen that the vast majority of the respondents concurred that miniature money brought challenging and fearlessness and redesigned their worth framework.

$>$ It is initiated that microfinance further developed the proficiency level of country ladies and further developed readiness on kids schooling to the majority of the respondents.

$>$ It is observed Majority of the respondents voiced that their mindfulness about climate worked on subsequent to participating in miniature money conspires effectively. Generally number of respondents have acknowledge that it has impacted a lot

$>$ It is seen that Women are monetarily and socially engaged subsequent to joining SHG and getting petty money had reduced the burden to some extent..

$>$ It is additionally seen that the vast majority of the ladies don't know about the trainings coordinated by the NGO. The NGO will effectively partake in different trainings meetings gave to all ladies individuals where in they can acquire information about the different pay creating exercises.

$>$ An unequivocal improvement in mental well is being and social strengthening among provincial ladies because of taking an interest in miniature money through SHG program.

\section{Conclusion}

From the overall efforts for this study the researcher would with bright face like to conclude that Empowerment is the power given to or acquire by an individual or group for the self determination and autonomy. It enhances the level of confidence and determination to prove the mettle and bring out the hidden performance and talent in someone. Micro finance is also not different from this which would make the self help group self sufficient and confident enough in doing some business related activity, which improves the standard of living of the society and the entrepreneur of his own kind. Recent history is very well evident regarding uplifting the weaker sections of the society to great extent, and has improved the life style and standard of living. Micro finance opportunity has dramatically changed the economic and psychological condition of the so called underestimated women to a promising level. This opportunity had significantly brought a revolutionary change in the living conditions of women and their families. 


\section{References}

1. C.R Kothari (2007) - Research Methodology Methods \& Techniques, Second Edition, New age International publishers, New Delhi

2. J \& a, Z. H. (2014). Microfinance around the world - regional SWOT Analysis. Prague: MPRA (Munich Personal RePEc Archieve). 13. The Indian Banker: I.B.A. Publication 14. Bank Quest : The Journal of Indian Institute of Banking \& Finance 15

3. K. Rajendran and R.P. Raya (2010) Impact of Micro Finance - An empirical Study on the Attitude of SHGLeaders in Vellore District (Tamil Nadu, India). 'Global Journal of Finance and Management'- $\quad$ ISSN $0975 \quad-6477$ Volume2, $\quad$ Number 1, $\quad$ pp.5968,http://www.ripublication.com/gjfm/gjfmv2n1_5.pdf.

4. Lap Lambert Academic Publishing. 11

5. Manjula Bolthajjira Chengappa."Micro-Finance and Women Empowerment:Role of Non government Organizations” .http://www.istr.org/Abstracts2010/pdf/ISTR2010_0212.pdf.

6. RanjulaBali Swaina and Fan YangWallentin(September2009)Does micro finance empower women Evidence from self-help groups in India, 'International Review of Applied Economics' Vol. 23, No. 5, , 541-556,http://pdfserve.informaworld.com/595379_758077589_913075296.pdf.

7. Rupapara, B, Patoliya, J. (2012). Problems faced by Microfinance Institutions \&Measures to solve it

8. S. P. Gupta (2009) -“Statistical methods", Thirty eight revised Editions, Sultan Chand \& Sons Publishers, New Delhi

9. Sa-Dhan. (2012). Financial Inclusion: A study on the efficacy of banking correspondent model. Delhi: City Foundation. 12 